\title{
PENGARUH TATA KELOLA PERUSAHAAN TERHADAP PREDIKTABILITAS LABA BANK UMUM KONVENSIONAL DI INDONESIA SELAMA PANDEMI COVID 19 DENGAN GENDER SEBAGAI VARIABEL MODERATING
}

\author{
Sri Rahayu' ${ }^{1)}$, Ken Sabardiman ${ }^{2)}$, Afrizal $^{3)}$ \\ ${ }^{1,2,3)}$ STMIK Bina Sarana Global Tangerang \\ Email: ayshiela.rafa@gmail.com
}

Diterima Tanggal 17 Mei 2021 / Disetujui Tanggal 12 Agustus 2021

\begin{abstract}
This study expects to dissect and acquire observational proof of the concussion of corporate administration on benefit consistency at conventional banking company in Indonesia during the Covid 19 pandemic and the concussion of sexual orientation (gender) on the causality connection between corporate administration and benefit consistency. Corporate administration is advanced by the piece of the leading group of chiefs, the amount of the leading body of magistrates, institutional possession, administrative proprietorship and review panels, while sex is the rasio of ladies on the leading body of organizations. Conventional commercial banks that recorded in Indonesia Stock Exchange are 43 banks, comprise of this investigation populace. Total sampletos are 33 conventional banks with purposive sampling as a sampling method. Moderated Regression Analysis is utilized as information investigation procedure. The outcomes acquired in this study showed that the amount of the leading body of magistrates, institutional possession, administrative proprietorship demonstrated to altogether influence benefit consistency. Sexual orientation (gender) altogether supports the concussion of administrative possession on benefit consistency. This research shows that it is compulsory to implement a good governance mechanism, the problems that will occur can be recognized early by the bank and the follow-up is done more quickly, in order that the bank can survive in a state of crisis. Affirmation of the concussion and role of ladies on the council can influence the causal relationship of corporate governance on earnings predictability.
\end{abstract}

Keywords : Corporate Governance, Gender, Profit Predictability

\begin{abstract}
ABSTRAK: Penelitian ini bertujuan untuk menganalisis dan mendapatkan bukti empiris pengaruh tata kelola perusahaan terhadap prediktabilitas laba bank umum konvensional di Indonesia selama masa pandemi Covid 19 dan pengaruh gender terhadap hubungan kausalitas antara tata kelola perusahaan dan prediktabilitas laba. Tata kelola diproksikan dengan komposisi dewan komisaris, size dewan komisaris, kepemilikan institusional, kepemilikan manajerial dan komite audit, sedangkan gender merupakan rasio perempuan dalam dewan eksekutif perusahaan. Seluruh bank umum konvensional yang tertera di Bursa Effek Indonesia berjumlah 43 bank dan merupakan populasi dalam riset ini. Sampel diperoleh sebanyak 33 bank dengan metode pengambilan sampel menggunakan purposive sampling. Analisis Regresi Moderasi digunakan sebagai teknik analisis data. Hasil yang diperoleh dalam penelitian ini yaitu bahwa ukuran dewan komisaris, kepemilikan institusional, kepemilikan manajerial terbukti berpengaruh terhadap prediktabilitas laba. Gender secara signifikan memperkuat pengaruh kepemilikan manajerial terhadap prediktabilitas laba. Penelitian ini menunjukkan bahwa perlunya penerapan mekanisme tata kelola yang baik, permasalahan yang akan terjadi dapat dikenali lebih awal oleh bank dan dilakukan tindak lanjut penyempurnaan yang lebih cepat, sehingga bank dapat bertahan dalam keadaan krisis. Penegasan dampak dan peran perempuan di dalam dewan dapat mempengaruhi hubungan kausalitas tata kelola perusahaan terhadap prediktabilitas laba.
\end{abstract}

Kata kunci : Tata Kelola Perusahaan, Gender, Prediktabilitas Laba 


\section{Pendahuluan}

Laba merupakan hal yang penting dalam suatu organisasi dimana menentukan keberhasilan dan keberlanjutan serta memengaruhi keputusan investor (Folajimi et al., 2019). Sebagai salah satu elemen laporan keuangan yang disajikan, laba menjadi bagian dari informasi kinerja perusahaan dan terkait dengan kontrak keagenan. Laba juga dijadikan dasar untuk rencana bonus, penghasilan yang terkait dengan perjanjian hutang, dan dikaitkan dengan biaya politik (Scott, 2012).

Laba yang berkualitas merupakan pendapatan yang mencakup karakteristik reliable dan relevance dimana informasi keuangan yang disajikan harus jujur dan menggambarkan seluruh transaksi-transaksi keuangan yang terjadi di perusahaan sehingga laporan keuangan menjadi representatif, terhindar dari kekeliruan dan tidak memihak, serta memberikan kejelasan mengenai aliran keuangan perusahaan secara lebih terperinci (SFAC, 2010). Relevance juga mengandung arti bahwa data mengenai laba yang diinformasikan pada laporan keuangan mempunyai nilai bukti dan nilai yang menguatkan. Laba memiliki kualitas yang baik saat memberikan gambaran yang akurat mengenai keadaan keuangan yang sebenarnya dan keberlanjutan perusahaan ( $\mathrm{Du}$ et al., 2020)

Khafid dan Arief (2017) mempersepsikan kualitas laba menjadi hal yang multidimensional, dengan demikian penentuan ukuran kualitas laba akan bergantung pada tersedianya informasi dan model riset serta pertanyaan yang diajukan dalam riset. Francis et al., dalam Khafid (2015) mengklasifikasikan delapan ukuran kualitas laba yang sering digunakan dalam riset-riset akuntansi, yaitu antara lain accruals standard, predictability, flatness, timelines, conservatism, value relevance, earnings informativeness, dan persistence.

Konsep laba berkualitas menjadi hal yang fundamental dalam akuntansi dan ekonomi keuangan, namun terdapat ketidaksepakatan yang luas tentang bagaimana itu harus didefinisikan dan diukur
(Dichev et al., 2012). Mengenai masalah pengukuran, perdebatan berfokus pada apakah berbasis akuntansi (kualitas akrual, manajemen laba, persistensi, prediktabilitas, dan kelancaran) atau indikator berbasis pasar (relevansi dan ketepatan waktu) adalah yang paling tepat untuk mengukur kualitas laba. Secara konseptual, bagaimanapun, kualitas dianggap tinggi jika pendapatan saat ini dapat lebih baik memprediksi arus kas masa depan, serta keuntungan jangka panjang, dari perusahaan (Dichev et al., 2012; Schiemann dan Guenther 2013).

Dari beberapa ukuran kualitas laba, yang paling sering digunakan adalah ukuran kualitas akrual, sedangkan prediktabilitas laba masih belum banyak dilakukan. Ukuran kualitas laba yang dihasilkan dengan menggunakan prediktabilitas laba dalam penelitian ini dilakukan untuk memperkenalkan ukuran kualitas laba dengan melihat kesesuaian laba.

Prediktabilitas laba menjadi salah satu ukuran kualitas laba yang penting karena berkaitan dengan seberapa baik pendapatan masa lalu dapat menjelaskan pendapatan saat ini dan masa depan dan ini dapat mengarah untuk penilaian yang lebih akurat karena memungkinkan investor untuk lebih mengantisipasi pendapatan masa depan yang diharapkan (Schiemann dan Guenther, 2013). Laba yang dihasilkan dikatakan berkualitas jika memiliki nilai yang diharapkan (IAI, 2011).

Francis et al., dalam Mollah et al., (2019) menyatakan bahwa angka laba yang dihasilkan yang menunjukkan replika sendiri merupakan angka laba yang memiliki nilai yang tinggi, dengan demikian hal ini menjadi dasar pandangan digunakannya prediktabilitas laba sebagai salah satu ukuran dari kualitas laba. Laba yang memiliki kualitas tinggi lebih representatif sebagai prediktor yang tepat untuk memprediksi laba yang akan datang. Lipe dalam Ginting (2014) mendefinisikan prediktabilitas laba sebagai kemampuan laba untuk memprediksi dirinya sendiri dan diperoleh dengan cara menghitung nilai dari ragam gejolak keuntungan yang dihasilkan (variety of 
earning fluctuation) dari keuntungan selama periode waktu tertentu.

Angka laba yang disajikan dalam laporan keuangan memberikan informasi penting yang memengaruhi investor pada keputusan investasinya. Hal inilah yang menjadi alasan mengapa perusahaan terkadang melakukan praktik keuangan yang tidak sehat dalam penyajian laporan keuangan (Folajimi et al., 2019). Manajemen sering memanipulasi pendapatannya karena berbagai alasan (Lee, 2013). Kualitas laba yang tidak baik membutuhkan tata kelola yang kuat agar dapat memastikan pengurangan informasi asimetris dan konflik keagenan antara manajer dan para stockholder (Salehi \& Asgari, 2013). Agency theory dan signaling theory menangani masalah manipulasi dalam konteks masalah asimetris informasi yang dikurangi melalui peningkatan tata kelola manajemen dan standar pelaporan ringkasan keuangan (Mollah et al., 2019). Mekanisme tata kelola yang kuat membuat manajer tidak leluasa dalam menjalankan aktivitas yang mungkin melakukan penipuan dalam pelaporan keuangan, sehingga meningkatkan kualitas dan keandalan pelaporan keuangan perusahaan tersebut (Heirany et al., 2013). Mekanisme tata kelola dilakukan untuk meningkatkan kualitas perusahaan dan kredibilitas laporan keuangan serta membatasi perilaku manajer (Lee, 2013).

Mekanisme tata kelola perusahaan yang kuat juga akan efektif memberikan tanda positif ke pasar dimana perusahaan dapat menciptakan keuntungan yang memadai setiap saat. Boediono dalam Khafid dan Arief (2017) mengungkapkan bahwa kepemilikan institusional, formasi dewan komisaris, dan kepemilikan eksekutif merupakan faktor-faktor yang diduga memengaruhi kualitas keuntungan yang dihasilkan. Keinginan manajer dalam mengelola keuntungan yang dihasilkan menjadi menurun dikarenakan adanya pihak yang mengawasi agen dengan kepemilikannya yang besar yaitu investor institusional (Jiang \& Anandarajan, 2009). Dampak dewan direksi terhadap integritas pelaporan keuangan karena tanggung jawabnya adalah melakukan pengawasan independen atas manajemen dan pelaporan kepada penyedia modal (Khafid dan Arief, 2017). Komite audit yang lebih besar dengan lebih banyak independensi memengaruhi kualitas laba (Hamdan, 2020). Indikator ukuran dewan komisaris yang tidak terlalu besar dan rapat yang harus dilakukan secara rutin meningkatkan fungsi pengawasan (Adebiyi, 2017). Dengan demikian, kualitas dari pelaporan keuangan yang disajikan membutuhkan implementasi mekanisme tata kelola perusahaan yang terstruktur dengan baik (Davies et al., 2016).

Berdasarkan feminist ethical theory terkait dengan tata kelola perusahaan, wanita memiliki perspektif yang berbeda dalam mengungkapkan ide dan gagasannya yang dapat memengaruhi kebijakan yang diputuskan (Machold et al., dalam Prastiwi dan Wiratno, 2021). Penelitian yang dilakukan oleh Mc Kinsey dan Company (2010) menunjukkan bahwa sebagian besar direksi menyadari diversifikasi dewan memengaruhi kinerja perusahaan menjadi lebih baik. Penelitian mengenai proporsi wanita dalam dewan dapat dilihat dari perbandingan kualitas perusahaan dari sudut pandang gender. Wanita yang berada dalam dewan perusahaan selama ini masih dipandang kurang mampu memimpin perusahaan karena ketegasannya yang kurang dalam pengambilan keputusan dan mempunyai naluri bersaing yang kurang dibandingkan dengan pria. Wanita juga sangat berhati-hati, memiliki kecenderungan untuk menghindari risiko dan lebih teliti, oleh karena itu kehadiran wanita dalam dewan dapat menunjang pengambilan keputusan yang lebih tepat dan lebih rendah risikonya (Anggraeni dan Djakman, 2017).

Jumlah perempuan di dewan juga memengaruhi konsistensi pendapatan bankbank besar (Mollah et al., 2015). Jumlah perempuan di dewan menggambarkan bahwa mereka dapat mengurangi risiko bank dan mengantisipasi keuntungan di masa depan. Meyer dan Levy (1986) mengungkapkan bahwa perempuan dalam mengelola dan menilai data atau informasi pada umumnya akan lebih terasah dan lengkap dengan memanfaatkan semua data secara total dan tidak menyerah begitu saja. Berbeda dengan pria dimana pilihan yang dibuat kurang menjangkau karena mereka tidak menggunakan semua data atau informasi yang dapat diakses. Perempuan dianggap memiliki kapasitas memori yang lebih baik mengenai data yang didapat daripada pria sehingga kemampuan untuk mengelola data 
atau informasi yang sedikit menjadi sedikit lebih tajam. Gender mengindikasikan kepada identitas sosial yang menggambarkan peranan sosial seseorang yang didasarkan pada jenis kelamin mereka di masyarakat (Naharin, 2017).

Literatur yang luas meneliti bagaimana tata kelola perusahaan dan kualitas pelaporan berdampak pada pendapatan, tetapi masalah ini hanya sedikit yang ditangani di bidang perbankan (Mollah et al., 2019). Perbankan adalah salah satu industri yang memiliki pedoman yang lebih ketat daripada perusahaan lain. Bank Indonesia mendasarkan pelaporan keuangan yang dibuat oleh bank, sebagai penentu situasi kondisi suatu bank. Kebutuhan akan aturan dan pengawasan berpusat pada ketergantungan moneter pada bank, sehingga memungkinkan pengelola perbankan memiliki daya dorong untuk mengontrol keuntungan yang dihasilkan agar sesuai dengan standar aturan Bank Indonesia. Konsistensi keuntungan yang diprediksi akan dihasilkan, menjadi hal penting bagi bank, hal ini seperti organisasi di bidang lain, bank juga sangat terikat pada pendapatan masa depan.

Penerapan tata kelola perusahaan dan manajemen risiko pada bank sangat penting dilakukan dengan tujuan agar permasalahan yang akan terjadi dapat dikenali lebih awal dan dapat dilakukan tindak lanjut untuk penyempurnaan secara lebih cepat dan sejenisnya, dengan demikian bisnis bank mampu bertahan meskipun dalam keadaan darurat (SE BI No. 15/15/DPNP/2013). Kompleksnya berbagai macam risiko yang dihadapi oleh kegiatan bisnis perbankan, menjadikan perlunya praktik tata laksana manajemen yang baik dengan memasukkan unsur identifikasi, estimasi, pengecekan, dan pengelolaan risiko bank (Peraturan OJK No. 18/POJK.03/2016).

Pandemi Covid-19 yang terjadi menjelang akhir tahun 2019, dan mulai menyebar ke Indonesia pada pertengahan tahun 2020 membuat isu di dunia perbankan. Pandemi ini menimbulkan permasalahan di sektor riil yang berakibat menimbulkan persoalan di sektor perbankan. Hal ini dikarenakan sektor perbankan menjadi lembaga penghubung atau perantara yang mendukung kebutuhan dana investasi bagi dunia usaha. Selama pandemi, banyak orang menarik aset mereka dalam cakupan yang sangat luas. Sejumlah tantangan juga dihadapi perbankan di Indonesia di tengah wabah Covid-19 dan hal ini dapat menyebabkan perbankan menghadapi beberapa resiko, seperti resiko pembiayaan macet (NPF), resiko pasar dan resiko likuiditas. Oleh karenanya, resiko tersebut pada akhirnya akan memiliki dampak terhadap kinerja dan profitabilitas perbankan. Pada tahun 2020, apabila dilihat dari tahuntahun sebelumnya keuntungan bersih bankbank BUMN berkurang. Penurunan keuntungan bersih bagi bank-bank BUMN tersebut dipicu oleh peningkatan pembayaran kerugian dari penurunan nilai (CKPN) atau pengaturan. Perluasan bobot administrasi disebabkan oleh upaya-upaya bisnis bank, dengan harapan dapat memperbaiki kondisi kredit yang buruk karena faktor penekan pandemi.

Kualitas pendapatan telah mendapat perhatian kebijakan yang cukup besar sejak krisis keuangan global ketika sistem perbankan secara substansial dibentuk kembali (Prior et al., 2014). Tata kelola yang efektif mendorong bank untuk mengambil tingkat risiko yang dapat diterima sambil meminimalkan kemungkinan kebangkrutan (Erkens et al., 2012). Hal ini memudahkan bank untuk merencanakan alokasi modal, investasi, dan memenuhi persyaratan regulasi. Ini juga membantu meningkatkan kepercayaan investor dan reputasi manajerial.

Berdasarkan latar belakang yang telah disebutkan sebelumnya, maka penelitian mengenai mekanisme tata kelola perusahaan dan gender pada industri perbankan di Indonesia selama pandemi Covid-19 menjadi rasional untuk dapat dilakukan. Prediktabilitas laba digunakan untuk melihat kualitas dari keuntungan yang dihasilkan. Secara khusus, gender dalam hal ini adalah rasio perempuan dalam dewan eksekutif dimasukkan sebagai variabel moderating. Tujuan penelitian ini yaitu melakukan pengujian empiris untuk:

1. Menganalisis dan mendapatkan bukti empiris mengenai pengaruh komposisi dewan komisaris, size dewan komisaris, kepemilikan institusional, kepemilikan manajerial dan komite audit terhadap prediktabilitas laba.

2. Menganalisis kehadiran perempuan yang merupakan rasio perempuan pada dewan eksekutif perusahaan dalam 
memengaruhi hubungan kausalitas antara komposisi dewan komisaris, size dewan komisaris, kepemilikan manajerial, kepemilikan institusional serta komite audit dan prediktabilitas laba.

\section{Pengembangan Hipotesis}

\section{Pengaruh Tata Kelola Perusahaan Terhadap Prediktabilitas Laba}

Tata kelola perusahaan berkaitan dengan proses, sistem, praktik dan prosedur yang mengatur lembaga serta penyelesaian masalah tindakan kolektif di antara investor yang tersebar dan rekonsiliasi konflik kepentingan antara dewan direksi, manajemen dan pemegang saham (Kumar, 2016). Tata kelola perusahaan juga mencakup wewenang untuk mengarahkan, mengatur, dan mengendalikan entitas perusahaan. Ini berkaitan dengan hubungan antara pemangku kepentingan yang sah dalam suatu perusahaan dan memastikan bahwa ada arahan yang tepat di perusahaan untuk pengembalian investasi yang wajar (Abdul-qadir, 2012).

Prinsip tata kelola perusahaan diperkenalkan sebagai mekanisme untuk mengurangi masalah keagenan. Indikatorindikator tata kelola perusahaan meningkatkan kualitas laba dengan memastikan bahwa laba tidak diarahkan secara artifisial ke arah tertentu. (Mokhtari \& Khosro, 2013). Mekanisme tata kelola yang kuat memastikan bahwa pelaporan keuangan selaras dengan pedoman pelaporan keuangan yang diadopsi dan bahwa perusahaan mengikuti tingkat pengungkapan informasi akuntansi yang sama (Khan et al., 2018). Mekanisme tata kelola diharapkan menjadi kendali perusahaan untuk mengurangi perilaku pengelolaan laba, yang dapat menurunkan kualitas laba (Saksessia \& Firmansyah, 2020)

Mekanisme tata kelola juga dapat mengurangi masalah keagenan dan meningkatkan kinerja bank. Karena pendapatan operasional merupakan kontributor utama kinerja bank. Mekanisme tata kelola yang efektif memberikan sinyal positif ke pasar mengenai kapasitas perusahaan untuk menghasilkan pendapatan yang cukup dari masa ke masa (Mollah et al., 2019). Struktur dewan, persyaratan pengungkapan dan kompetensi anggota dewan dari masa ke masa memiliki pengaruh yang signifikan terhadap praktik tata kelola dan kemudian meningkatkan kinerja operasi bank (Orazalin \& Mahmood, 2019). Berdasarkan teori keagenan, dapat dinyatakan bahwa manajemen perusahaan memiliki kedudukan penting dalam meningkatkan kualitas pelaporan keuangan (Wiralestari, 2015).

Hasil riset Khafid (2015) menunjukkan kepemilikan manajerial memengaruhi prediktabilitas laba, sedangkan komposisi dewan komisaris, jumlah komite audit, dan kepemilikan institusional tidak memengaruhi prediktabilitas laba. Sebagai variabel moderating, kepemilikan institusional memengaruhi hubungan kausalitas kepemilikan manajerial terhadap prediktabilitas laba. Struktur dewan dan kekuasaan CEO mempunyai pengaruh yang fundamental pada prediktabilitas laba (Mollah et al, 2015).

H1: Prediktabilitas laba signifikan dipengaruhi oleh komposisi dewan komisaris, size dewan komisaris, kepemilikan institusional, kepemilikan manajerial dan komite audit secara bersama-sama

\section{Pengaruh Komposisi Dewan Komisaris Terhadap Prediktabilitas Laba}

Dewan komisaris independen bertugas mengawasi strategi yang dibuat manajemen dan bertindak selaku penengah dalam konflik yang terjadi diantara manajer internal sehingga dapat menciptakan sistem tata kelola perusahaan yang baik yang berdampak pada kualitas laba yang dihasilkan. (Afnan, 2014). Kualitas tata kelola perusahaan yang baik, akan menghasilkan dewan komisaris independen yang secara memadai mengawasi kegiatan dan tindakan manajemen dalam menyiapkan laporan keuangan perusahaan, sehingga pelaporan keuangan yang dihasilkan memiliki nilai dengan kualitas laba yang tinggi (Khafid, 2015). Terlibatnya dewan komisaris sebagai pihak yang memberikan tanggung jawab melakukan fungsi monitoring secara independen terhadap hasil kinerja manajemen, kemudian memberikan pertanggungjawaban segala kegiatan yang telah dilakukan oleh perusahaan kepada para 
stockholder, merupakan salah satu faktor yang penting yang berpengaruh pada kredibilitas proses akuntansi sebuah perusahaan (Jiraporn et al., 2012). Dampak dewan komisaris independen terhadap integritas pelaporan keuangan karena tanggung jawabnya adalah ketentuan pengawasan independen atas manajemen dan pelaporan kepada penyedia modal (Khafid \& Arief, 2017). Mollah et al., 2019 menyatakan bahwa terdapat bukti empiris yang konsisten dengan teori pensinyalan yang dibangun di atas pelaporan keuangan di bawah rezim IFRS / GAAP serta prediksi teori agensi dari lingkungan peraturan mengenai struktur komposisi dewan dalam menjelaskan prediktabilitas laba.

$\mathrm{H} 2$ : Prediktabilitas laba dipengaruhi secara signifikan oleh komposisi dewan komisaris.

\section{Pengaruh Size Dewan Komisaris Terhadap Prediktabilitas Laba}

Efek dari ukuran interaktif tata kelola pada prediktabilitas pendapatan, khususnya dewan kecil dan independen meningkatkan prediktabilitas pendapatan (Mollah et al., 2019). Pengelolaan laba perusahaan dipengaruhi oleh ukuran dewan komisaris. Nasution dan Setiawan dalam Kodriyah (2015) menyatakan bahwa terdapat pengaruh positif yang fundamental terhadap praktik pengelolaan laba pada perusahaan di perbankan. Semakin banyak dewan komisaris pada perusahaan, maka semakin banyak pula pengelolaan laba yang dilakukan perusahaan. Hal ini memperlihatkan bahwa dewan komisaris yang banyak tidak efektif dalam mencegah praktik pengelolaan laba. Didasarkan pada keagenan, dewan komisaris independen berperan sebagai mekanisme internal control paling tinggi, yang memiliki fungsi dan tanggung jawab untuk melakukan pengawasan atas perilaku manajemen puncak. Fungsi pengawasan ini dapat mengurangi kecenderungan manajer dalam tindakannya melakukan manajemen laba, dengan demikian investor dapat tetap percaya untuk menanamkan investasinya pada perusahaan. (Aprilliani \& H, 2017).

H3: Prediktabilitas laba dipengaruhi secara signifikan oleh size dewan komisaris.

\section{Pengaruh Kepemilikan Institusional Terhadap Prediktabilitas Laba}

Pemegang saham institusional karena persentase kepemilikan sahamnya yang tinggi berada dalam posisi untuk melakukan kontrol atas tindakan manajer. Mempertimbangkan kekuatan dan motif investor institusional dalam membujuk manajer untuk memberikan laporan laba yang berkualitas tinggi dan dalam memberikan mereka insentif untuk peningkatan kinerja, pemilik institusional dapat memengaruhi nilai perusahaan dan kualitas laba yang dihasilkan (Mokhtari \& Khosro, 2013). Pemilik institusional mempunyai keleluasaan informasi yang dimiliki perusahaan, dalam penentuan harga saham mereka dengan mengandalkan informasi historis, dan dengan meyakinkan manajer untuk pelaporan yang tepat waktu dan akurat, sehingga pada akhirnya berkontribusi pada peningkatan pelaporan keuangan termasuk kualitas dari laba yang dihasilkan (Mokhtari \& Khosro, 2013). Kedudukan pemegang saham institusional dalam memengaruhi pilihan manajerial merupakan bagian penting dari sistem hak investor. Pemegang saham institusional akan lebih efektif terlibat dengan organisasi yang mereka miliki ketika kepemilikan institusional berkembang (Jiang \& Anandarajan, 2009). Kepemilikan institusional adalah kelompok yang mengawasi manajer dengan kepemilikan yang besar, sehingga dapat mencegah dan menurunkan keinginan manajer untuk mengelola angka-angka akuntansi pada laporan keuangan. Tindakan manajer yang mengelola angka-angka akuntansi dapat dicegah oleh mekanisme pengawasan yang efektif seiring meningkatnya kepemilikan institusional, hal ini dinyatakan oleh teori keagenan (Jensen \& Meckling, 1976).

H4: Prediktabilitas laba dipengaruhi secara signifikan oleh kepemilikan institusional

\section{Pengaruh Kepemilikan Manajerial Terhadap Prediktabilitas Laba}

Teori keagenan dan bukti empiris menunjukkan bahwa kemampuan dan insentif pemilik untuk melakukan upaya pemantauan dan mengurangi masalah keagenan bervariasi 
dengan struktur kepemilikan manajerial (Bourkhis, 2017). Jensen dan Meckling (1976) mengungkapkan bahwa dalam konsep agency theory untuk meminimalkan perilaku manipulasi manajer dilakukan upaya pemantauan. Teori keagenan memperkirakan bahwa semakin sedikit kepemilikan perusahaan oleh seorang manajer, maka memiliki insentif yang lebih tinggi dalam melakukan pengelolan angka-angka akuntansi untuk dapat menghilangkan rintanganrintangan yang terdapat pada kesepakatan remunerasi berdasarkan akuntansi. Konsisten pada teori ini, Khafid (2015) menemukan hubungan positif antara kepemilikan manajerial dan kualitas laba. Hasil temuan ini sesuai dengan keyakinan bahwa salah satu mekanisme mendisiplinkan adalah dengan berfungsinya kepemilikan saham manajerial.

H5: Prediktabilitas laba dipengaruhi secara signifikan oleh kepemilikan manajerial

\section{Pengaruh Komite Audit Terhadap Prediktabilitas Laba}

Tugas komite audit sangatlah penting dalam memengaruhi kualitas keuntungan yang dihasilkan oleh perusahaan. Kewajiban komite audit adalah memberikan saran atas penentuan pengaudit dari luar perusahaan kepada dewan, mengawasi kebebasan pengaudit luar perusahaan dari manajemen, dan memastikan kualitas dan kecukupan pembukuan dari praktik akuntansi, serta praktik internal control yang dijalankan perusahaan. Kebebasan dan kepercayaan dalam kegiatan pemeriksaan menentukan kemampuan dan keberhasilan pelaporan keuangan yang disajikan. Teori keagenan mengungkapkan upaya untuk mengawasi dan mengurangi informasi yang tidak seimbang antara agen dan pemilik adalah dengan kehadiran komite audit (Khafid, 2015). Komite audit berfungsi sebagai mekanisme tata kelola perusahaan yang mengkoordinasikan audit internal, audit eksternal, dan pemantauan kinerja perusahaan dalam mendukung pelaporan keuangan berkualitas tinggi atas kualitas laba yang dihasilkan (Hamdan, 2020).

H6: Prediktabilitas laba dipengaruhi secara signifikan oleh komite audit

\section{Moderasi Gender Pada Hubungan}

\section{Kausalitas Tata Kelola Perusahaan Terhadap Prediktabilitas Laba}

Pada konsep feminisme, gender memiliki makna sebagai identitas atau karakter yang dikaitkan dengan seks tertentu, seperti budaya, maupun kepribadian psikologis, bukan pada perbedaan biologis yang dimiliki seseorang. Secara mudah perbedaan arti seks sebagai jenis kelamin biologis dari lahir, yakni pria atau wanita yang didasarkan pada alat kelamin yang dimiliki, di sisi lain gender dalam konsep sosial didefinisikan sebagai ciri maskulin atau feminim pada konstruksi sosial budaya. (Khuza'i, 2012).

Filsafat dan hipotesis mengenai orientasi seks (gender) mengarah pada hipotesis feminisme, yaitu hipotesis yang menyatakan bahwa perjuangan dari semua aktivis perempuan adalah berupaya mendapatkam kesetaraan status, kebebasan (otonomi) dan memiliki pekerjaan sosial yang serupa di dalam masyarakat sehingga tidak mungkin ada lagi ketidakseimbangan orientasi seksual di area publik.

Menurut resource dependence theory, direktur wanita yang terlibat dalam kegiatan sosial akan lebih peduli dan peka terhadap lingkungan dibandingkan dengan direktur pria (Beji et al., 2020). Teori lain yang menjelaskan dorongan wanita dalam dewan adalah upper echelons theory. Hambrick (2016) mengungkapkan bahwa prinsip utama dari upper echelons theory adalah pengalaman pribadi, nilai, dan kepribadian individu masing-masing sangat memengaruhi penafsiran yang dilakukan oleh para eksekutif perusahaan pada situasi dan kondisi yang sedang mereka hadapi. Sebagian besar orang akan menyatakan bahwa logika lebih banyak digunakan oleh pria sedangkan perasaan lebih banyak digunakan oleh wanita. Dengan didasarkan pada sifat wanita yang cenderung lebih teliti, sangat berhati-hati, memiliki kecenderungan untuk menghindari risiko tentunya membuat wanita lebih unggul dalam hal kepedulian, termasuk dalam hal profitabilitas perusahaan.

Yogiswari dan Badera, (2019) menyatakan bahwa keberadaan wanita pada anggota dewan perusahaan memengaruhi perusahaan untuk mampu mempunyai kinerja yang lebih baik dibandingkan dengan perusahaan yang tidak mempunyai anggota 
dewan wanita, di sisi lain apabila wanita menduduki posisi top management dalam perusahaan maka kinerja keuangan akan semakin tinggi.

Jenis kelamin pada dewan dapat memengaruhi manajemen laba perusahaan ketika dewan perusahaan memiliki insentif yang kuat untuk meningkatkan laba. (ElMahdy, 2015). Pria dan wanita menunjukkan kecenderungan gaya leadership yang tidak sama. Kaum pria tidak sepenuhnya memanfaatkan informasi atau data yang ada dalam menyusun informasi sehingga pilihan yang mereka putuskan menjadi tidak terlalu teliti. Berbeda dengan wanita, informasi yang diolah lebih cenderung lengkap dan teliti, tidak mudah menyerah dan memikirkan kembali informasi atau data yang ada (Meyer \& Levy, 1986).

Peran moderasi gender dalam hubungannya dengan mekanisme tata kelola dan prediktabilitas laba, untuk melihat apakah dengan adanya penambahan proporsi wanita dalam dewan dapat memperkuat atau memperlemah pengaruh mekanisme tata kelola yang diproksikan dengan komposisi dewan komisaris, size dewan komisaris, kepemilikan institusional, kepemilikan manajerial, serta komite audit terhadap prediktabilitas laba. Hal ini didasarkan pada perspektif bisnis mengenai argumen kesetaraan kesempatan bagi wanita yang berfokus pada fakta bahwa keberadaan wanita dalam dewan perusahaan adalah suboptimal bagi perusahaan. Wanita dianggap sulit untuk memperoleh kursi dalam dewan komisaris dan direksi karena mereka harus menghadapi berbagai tantangan sehingga apabila wanita berada dalam jajaran dewan perusahaan merupakan suatu kehormatan bagi wanita. Perempuan juga pada umumnya mengalami tingkat stress yang lebih tinggi dari pada lakilaki, terutama jika mereka bekerja di bagian yang didominasi oleh laki-laki (Matud, 2015).

Efek moderasi gender juga untuk melihat apakah dengan semakin bertambahnya size dewan komisaris dengan semakin banyaknya perempuan dalam dewan akan memperkuat tindakan manajemen untuk mampu memprediksi laba karena sifat dasar perempuan yang cenderung menyeimbangkan risk-taking dengan lebih berhati-hati untuk menghindari risiko (risk-averse). Jika kepemilikan institusional dan kepemilikan manajerial bertambah, adanya perempuan dalam dewan akan memperkuat tindakan manajemen untuk mampu memprediksi laba. Perusahaan dengan dewan beragam cenderung membayarkan dividen lebih besar dibandingkan dengan dewan perusahaan yang tidak beragam (Byoun et al., 2016). Bertambahnya jumlah anggota komite audit dengan adanya kehadiran wanita dalam dewan akan mengurangi risiko restatement laporan keuangan dan memperkuat tindakan manajemen untuk mampu memprediksi laba karena sifat dan kelebihan yang dimiliki oleh seorang wanita (Abbot et al, 2010)

Berdasarkan pemikiran tersebut di atas, maka hipotesis selanjutnya dirumuskan sebagai berikut:

H7: Gender memoderasi pengaruh komposisi dewan komisaris terhadap prediktabilitas laba.

H8: Gender memoderasi pengaruh size dewan komisaris terhadap prediktabilitas laba.

H9: Gender memoderasi pengaruh kepemilikan institusional terhadap prediktabilitas laba.

H10: Gender memoderasi pengaruh kepemilikan manajerial terhadap prediktabilitas laba.

H11: Gender memoderasi pengaruh komite audit terhadap prediktabilitas laba.

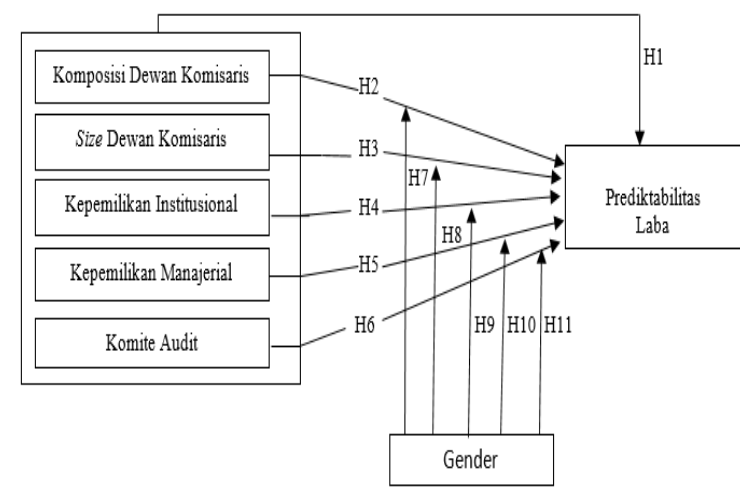

Gambar 1. Model Penelitian Empiris

\section{Metode Penelitian}

\section{Populasi, Sampel, Jenis dan Sumber Data}

Penelitian ini termasuk penelitian kuantitatif dimana sumber data diperoleh dari sumber data yang telah ada (Bougie dan Sekaran, 2016). Data pada annual report (laporan tahunan) perusahaan perbankan 
konvensional yang tertera di Bursa Efek Indonesia (BEI) digunakan untuk memperoleh data pada riset ini. Data ini juga diperoleh dari Indonesian Capital Market Directory (ICMD), homepage BEI www.idx.co.id, serta melakukan akses langsung ke situs masing-masing perusahaan sampel.

Seluruh perusahaan perbankan konvensional yang tertera di Bursa Efek Indonesia (BEI) selama periode tahun 20162020 merupakan populasi pada riset ini, dan purposive sampling adalah teknik yang dilakukan untuk pengambilan sampel. Analisis regresi moderasi digunakan sebagai teknik analisis data dengan menggunakan SPSS v20. Beberapa kriteria digunakan untuk menjadi dasar pengambilan sampel pada riset ini. Adapun kriteria yang mendasari pemilihan sampel ditunjukkan pada tabel 1 .

Tabel 1. Kriteria Pengambilan Sampel

\begin{tabular}{|c|c|}
\hline Kriteria & Jumlah \\
\hline $\begin{array}{l}\text { Perusahaan } \begin{array}{c}\text { perbankan } \\
\text { konvensional yang terdaftar }\end{array}\end{array}$ & 43 \\
\hline
\end{tabular}

di Bursa Efek Indonesia

(BEI) periode tahun 2016-

2020 dan sudah go public.

Perusahaan yang tidak menerbitkan laporan periode tahun 2016-2020

Perusahaan yang memiliki

data outlier

Jumlah perusahaan yang

dijadikan sampel dalam

penelitian

Total sampel yang 165
digunakan dalam penelitian
( 33 x 5 tahun)

Berdasarkan tabel 1 di atas maka sampel yang diperoleh sebanyak 33 perusahaan perbankan konvensional dari populasi sebanyak 43 perusahaan perbankan konvensional di Indonesia.

\section{Variabel Penelitian}

Variabel dependen pada riset ini adalah prediktabilitas laba, sedangkan variabel independennya terdiri dari: komposisi dewan komisaris, size dewan komisaris, kepemilikan institusional,

Kepemilikan manajerial, dan komite audit. Gender yang merupakan rasio perempuan dalam dewan adalah variabel moderating. Ringkasan dari masing-masing variabel, definisi operasional dan cara pengukurannya dapat dilihat pada tabel 2 .

Tabel 2. Ringkasan Variabel Penelitian

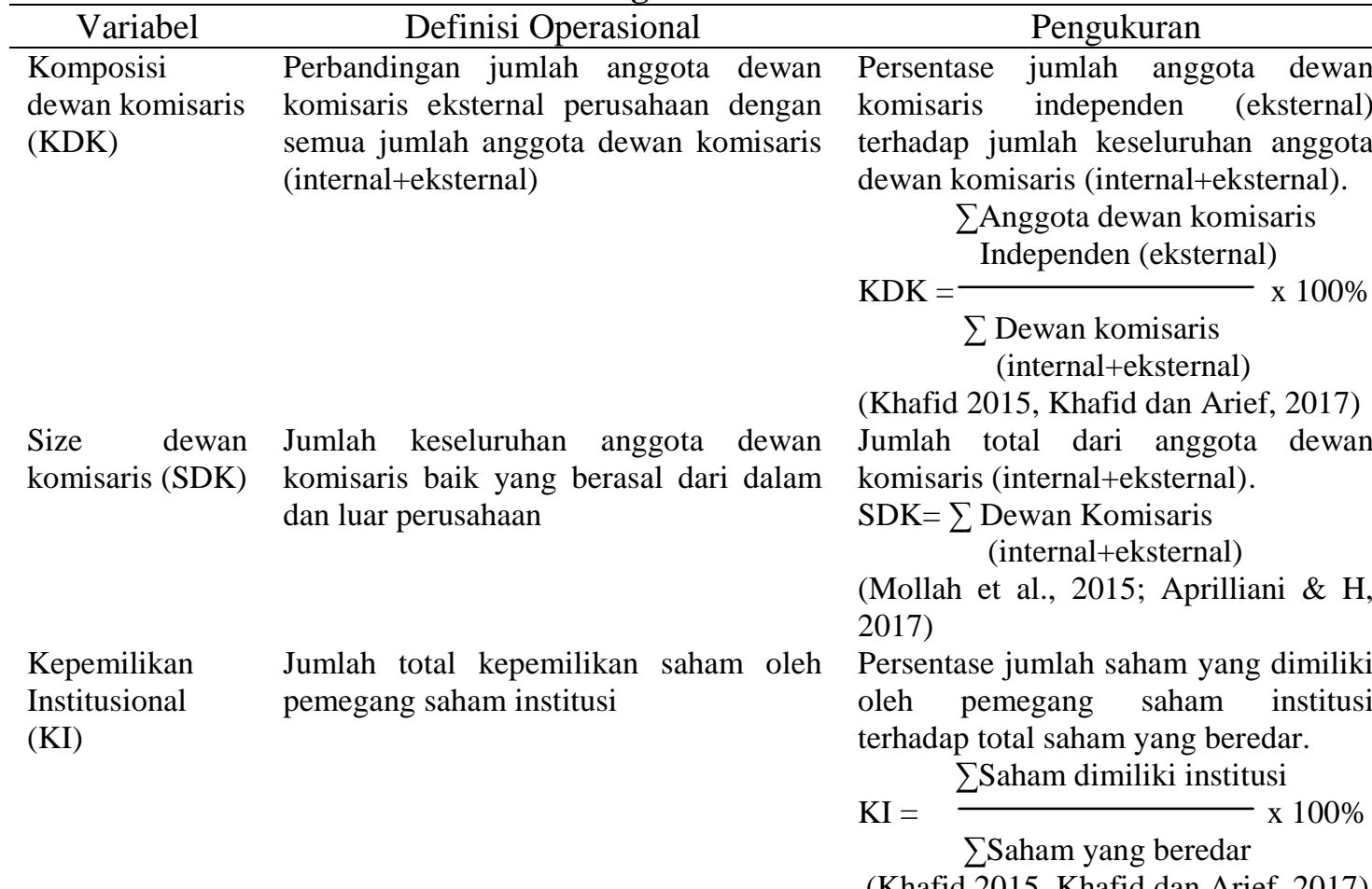

(Khafid 2015, Khafid dan Arief, 2017) 
Kepemilikan Manajerial $(\mathrm{KM})$

Jumlah total saham yang dimiliki oleh dewan komisaris dan direksi

Komite Audit (KA)

Komite yang dibuat dewan komisaris untuk membantu melaksanakan tugas dan fungsinya

\begin{tabular}{lll}
\hline Gender & Rasio perempuan dalam dewan \\
(GND) & perusahaan
\end{tabular}

Prediktabilitas Laba (PL)
Proporsi kualitas laba yang bergantung pada kemampuan laba untuk dapat meramalkan keuntungan itu sendiri
Persentase jumlah saham yang dimiliki oleh masing-masing anggota dewan komisaris dan direksi terhadap total saham yang beredar.

Saham yang dimiliki

$\sum$ dewan komisaris dan direksi

$\mathrm{KM}=\frac{}{\sum \text { Saham yang beredar }} \times 100 \%$

(Khafid 2015, Khafid dan Arief, 2017)

Jumlah total anggota komite audit yang ada di perusahaan.

$\mathrm{KA}=\sum$ Anggota Komite Audit (Khafid 2015, Khafid dan Arief, 2017)

Prosentase jumlah perempuan dalam dewan komisaris dan direksi perusahaan terhadap keseluruhan anggota dewan.

Perempuan dalam

$\sum$ dewan komisaris dan direksi

(Mollah et al., 2015; Mollah et al., 2019)

Variansi goncangan laba akuntansi dari laba akuntansi runtut waktu atau nilai keslahan (residual) dari persamaan regresi dalam perhitungan persistensi laba dengan rumus :

$$
\begin{array}{ll}
\mathrm{E}_{\mathrm{it}}=\mathrm{a}+ & \mathrm{bE}_{\mathrm{it}-1}+\varepsilon \\
\text { Dimana, } & \\
\mathrm{t} \quad & \text { laba akuntansi perusahaan } \mathrm{i} \\
& \text { pada tahun } \mathrm{t} \\
\mathrm{E}_{\mathrm{it}-1} \quad & \text { laba akuntansi perusahaan } \mathrm{i} \\
& \text { pada tahun lebih awal dari } \\
& \text { tahun } \mathrm{t} \\
= & \text { variansi goncangan laba } \\
& \text { akuntansi dari laba akuntansi } \\
& \text { runtut waktu }
\end{array}
$$

(Ginting, 2014)

\section{Metode Analisis Data}

Metode analisis yang digunakan dalam penelitian ini menggunakan analisis statistik inferensial berupa analisis regresi moderasi (Moderated Regression Analysis). Uji asumsi klasik berupa uji normalitas, multikolonieritas, autokorelasi dan heteroskedastisitas juga dilakukan untuk memperoleh model yang BLUE (Best, Linear, Unbiased Estimator).

Persamaan model Moderated Regression Analysis adalah sebagai berikut :

$$
\begin{aligned}
& Y=a+b 1 X_{1}+b 2 X_{2}+b 3 X_{3}+b 4 X_{4}+b 5 X_{5}+ \\
& \text { e...... }
\end{aligned}
$$
e.

Dimana :

Y : Prediktabilitas laba

$\mathrm{X}_{1} \quad$ : Komposisi dewan komisaris

$\mathrm{X}_{2} \quad$ : Size dewan komisaris

$\mathrm{X}_{3} \quad$ : Kepemilikan institusional 
$\mathrm{X}_{4} \quad$ : Kepemilikan manajerial

$\mathrm{X}_{5} \quad$ : Komite audit

W : Gender

$\mathrm{X}_{1} * \mathrm{~W}$ :Interaksi komposisi dewan komisaris dan gender

$\mathrm{X}_{2}{ }^{*} \mathrm{~W}$ :Interaksi size dewan komisaris dan gender

$\mathrm{X}_{3} * \mathrm{~W}$ :Interaksi kepemilikan institusional dan gender

$\mathrm{X}_{4} * \mathrm{~W}$ : Interaksi kepemilikan manajerial dan gender

$\mathrm{X}_{5} * \mathrm{~W} \quad$ : Interaksi komite audit dan gender

Pengujian model 2 dilakukan untuk melihat gender sebelum diuji signifikansinya sebagai variabel moderating, gender diuji terlebih dahulu sebagai variabel bebas (independent variable). Hal tersebut dilaksanakan sebagaimana umumnya pengujian variabel moderating dilakukan (Ghozali, 2018). Persamaan regresi model 2 dan 3 digunakan untuk menentukan jenis variabel moderator. Jika pada model 2 dan model 3 berbeda secara signifikan atau hasil uji $\mathrm{b} 6 \neq 0 ; \mathrm{b} 7=0 ; \mathrm{b} 8=0 ; \mathrm{b} 9=0 ; \mathrm{b} 10=0 ; \mathrm{b} 11=0$ maka gender bukanlah variabel moderator, tetapi sebagai variabel independen. Variabel gender merupakan variabel pure moderator jika model 2 dan 3 berbeda b6 $=0 ; \quad b 7 \neq 0$; b8 $\neq 0$; b9 $\neq 0 ; b 10 \neq 0 ; b 11 \neq 0$.

\section{Hasil Dan Pembahasan \\ Hasil Uji Asumsi Klasik}

Hasil uji asumsi klasik pada penelitian ini telah memenuhi semua syarat uji asumsi klasik, dimana untuk uji normalitas dengan menggunakan uji One's Sample KolmogorovSmirnov Test menunjukkan bahwa data residual berdistribusi normal. Hasil uji multikolonieritas memperlihatkan bahwa tidak terjadi multikolonieritas pada model regresi yang dibentuk. Hasil uji autokorelasi dengan menggunakan uji Lagrange Multiplier (LM Test) menunjukkan tidak terjadi autokorelasi. Sedangkan hasil uji Park menunjukkan bahwa model regresi ini tidak ada heteroskesdastisitas.

\section{Hasil Uji Regresi Model 1}

Hasil pengujian pada model regresi pertama adalah untuk mengetahui pengaruh komposisi dewan komisaris, size dewan komisaris, kepemilikan institusional, kepemilikan manajerial, dan komite audit terhadap prediktabilitas laba, dan dapat dilihat pada tabel 3 .

Tabel 3. Hasil Analisis Regresi Model 1

\begin{tabular}{lccc}
\hline Keterangan & Koefisien Regresi & t-hitung & Sig \\
\hline Konstanta & $-857986,88$ & & \\
Komposisi dewan komisaris & 0,105 & 1,152 & .252 \\
Size dewan komisaris & 0,441 & 4,384 & .000 \\
Kepemilikan Institusional & $-0,237$ & $-2,696$ & .008 \\
Kepemilikan Manajerial & 0,256 & 3,020 & .003 \\
Komite Audit $\quad: 0,589$ & 0,078 & 0,816 & .416 \\
R & & & \\
Adjusted R Square : 0,312 & & & .000 \\
F Test 9,975 & & & \\
\hline
\end{tabular}

Sumber : Hasil olah data sekunder, 2021

\section{Uji Signifikansi Simultan (Uji F)}

Berdasarkan hasil analisis regresi model 1 pada tabel 3 tersebut di atas, nilai $\mathrm{F}$ hitung menunjukkan angka sebesar 9,975 dengan taraf signifikansi sebesar 0,000. Angka signifikansi ini menunjukkan angka yang jauh lebih kecil dari 0,05 , dapat dinyatakan bahwa model regresi ini fit dan dapat digunakan untuk memprediksi laba. Hasil ini juga menunjukkan bahwa prediktabilitas laba dipengaruhi secara signifikan oleh keseluruhan prediktor secara bersama-sama dimana prediktor tersebut meliputi komposisi dewan komisaris, size dewan komisaris, kepemilikan institusional, kepemilikan manajerial, dan komite audit. Dengan demikian hipotesis 1 dalam penelitian ini dinyatakan diterima.

2. Uji Koefisien Determinasi $\left(\mathrm{R}^{2}\right)$

Besarnya kemampuan variasi dari keseluruhan variabel bebas dalam mendeskripsikan variasi variabel terikat dapat menggunakan analisis koefisien determinasi (Ghozali, 2018). Pada tabel 3, 
diperoleh angka adjusted $R$ Square sebesar 0,312 . Hal ini berarti $31,2 \%$ variasi prediktabilitas laba dapat dijelaskan oleh kelima variabel independennya yaitu komposisi dewan komisaris, size dewan komisaris, kepemilikan institusional, kepemilikan manajerial, komite audit. Sedangkan sisanya dideskripsikan oleh unsur lain yang terdapat di luar model penelitian ini.

3. Uji Signifikansi Parameter Individual (Uji t) Melalui hasil uji $\mathrm{t}$ pada model regresi 1 dapat diketahui bahwa size dewan komisaris, kepemilikan institusional dan kepemilikan manajerial secara parsial berpengaruh secara signifikan terhadap prediktabilitas laba. Hal ini dapat dilihat dari angka signifikansi t yang lebih kecil dari 0.05 , yaitu $0,000,0,008$, dan 0,003 , sehingga bisa ditarik kesimpulan bahwa hipotesis 3, hipotesis 4, dan hipotesis 5 diterima. Prediktabilitas laba tidak dipengaruhi oleh komposisi dewan komisaris dan komite audit. Hal ini dapat dilihat dari angka signifikansi t yang jauh lebih tinggi dari 0.05 yaitu 0,252 dan 0,416, dengan demikian dapat dinyatakan bahwa hipotesis 2 dan hipotesis 6 ditolak.

\section{Hasil Uji Moderated Regression Analysis}

Hasil pengujian statistik untuk uji Moderated Regression Analysis diperlihatkan pada tabel 4.

Tabel 4. Hasil Analisis Regresi Model 3

\begin{tabular}{|c|c|c|c|}
\hline Keterangan & Koefisien Regresi & t-hitung & Sig \\
\hline Konstanta & $-420598,97$ & & \\
\hline Komposisi dewan komisaris & .062 & .661 & .511 \\
\hline Size dewan komisaris & .439 & 3.771 & .000 \\
\hline Kepemilikan Institusional & -.319 & -3.449 & .001 \\
\hline Kepemilikan Manajerial & .295 & 3.340 & .001 \\
\hline Komite Audit & .094 & .962 & .339 \\
\hline Gender & -.041 & -.430 & .668 \\
\hline $\mathrm{KDK} * \mathrm{GND}$ & -.230 & -1.234 & .220 \\
\hline $\mathrm{SDK}^{*} \mathrm{GND}$ & -.173 & -1.070 & .288 \\
\hline KI*GND & .107 & .644 & .521 \\
\hline $\mathrm{KM} * \mathrm{GND}$ & .359 & 2.199 & .031 \\
\hline KA*GND & -.125 & $-1,452$ & .150 \\
\hline $\mathrm{R} \quad: 0,640$ & & & \\
\hline \multicolumn{4}{|l|}{ Adjusted R Square : 0,336 } \\
\hline F Test $\quad: 5,560$ & & & .000 \\
\hline
\end{tabular}

Sumber : Hasil olah data sekunder, 2021

1. Uji Signifikansi Simultan (Uji F)

Berdasarkan hasil analisis regresi model 3 tersebut di atas, nilai $\mathrm{F}$ hitung menunjukkan angka sebesar 5,560 dengan taraf signifikansi sebesar 0,000. Angka signifikansi ini menunjukkan angka yang jauh lebih kurang dari 0,05 maka dapat dinyatakan bahwa bentuk regresi ini fit dan dapat digunakan untuk memprediksi laba. Hasil ini juga menunjukkan bahwa prediktabilitas laba dipengaruhi secara signifikan oleh keseluruhan prediktor secara bersama-sama dimana prediktor tersebut meliputi komposisi dewan komisaris, size dewan komisaris, kepemilikan institusional, kepemilikan manajerial, komite audit, gender, interaksi komposisi dewan komisaris dengan gender, interaksi size dewan komisaris dengan gender, interaksi kepemilikan institusional dengan gender, interaksi kepemilikan manajerial dengan gender, dan interaksi komite audit dengan gender.

2. Uji Koefisien Determinasi $\left(\mathrm{R}^{2}\right)$

Pada regresi model 3 ini diperoleh angka adjusted $R$ Square sebesar 0,336. Hal ini menunjukkan bahwa $33,6 \%$ variasi prediktabilitas laba dapat diungkapkan oleh variabel independennya yaitu komposisi 
dewan komisaris, size dewan komisaris, kepemilikan institusional, kepemilikan manajerial, komite audit, gender, interaksi komposisi dewan komisaris dengan gender, interaksi size dewan komisaris dengan gender, interaksi kepemilikan institusional dengan gender, interaksi kepemilikan manajerial dengan gender, dan interaksi komite audit dengan gender. Sedangkan sisanya dijelaskan oleh faktor lain di luar model pada riset ini.

3. Uji Signifikansi Parameter Individual (Uji t)

Melalui hasil uji t pada tabel 4 dapat diketahui bahwa size dewan komisaris, kepemilikan institusional dan kepemilikan manajerial secara parsial berpengaruh secara signifikan terhadap prediktabilitas laba. Hal ini dapat dilihat dari angka signifikansi t yang lebih kecil dari 0.05 , yaitu $0,000,0,001$, dan 0,001 , sehingga bisa ditarik kesimpulan bahwa hipotesis 3, hipotesis 4, dan hipotesis 5 diterima. Prediktabilitas laba tidak dipengaruhi oleh komposisi dewan komisaris dan komite audit. Hal ini dapat dilihat dari angka signifikansi $\mathrm{t}$ yang jauh lebih tinggi dari 0.05 yaitu 0,252 dan 0,416 , dengan demikian dapat dinyatakan bahwa hipotesis 2 dan hipotesis 6 ditolak. Hasil pengujian variabel gender sebagai variabel independen menunjukkan bahwa gender tidak berpengaruh secara signifikan terhadap prediktabilitas laba, dengan nilai signifikansi $\mathrm{t}$ sebesar 0,668 jauh lebih tinggi dari 0,05 . Hasil riset ini juga menunjukkan bahwa moderasi rasio perempuan dalam dewan pada hubungan kausalitas pelaksanaan mekanisme tata kelola dan prediktabilitas laba hanya terjadi melalui kepemilikan manajerial. Hal ini diperlihatkan dari nilai signifikansi $t$ variabel interaksi kepemilikan manajerial dengan gender yang memperlihatkan angka 0,031 dibawah angka 0,05 , sedangkan melalui komposisi dewan komisaris, size dewan komisaris, kepemilikan institusional dan komite audit dampak moderasi gender tidak terjadi, dengan nilai signifikansi $\mathrm{t}$ variabel interaksi komposisi dewan komisaris, size dewan komisaris, kepemilikan institusional dan komite audit dengan gender yang nilainya di atas 0,05 , sehingga dapat dinyatakan bahwa hipotesis 10 diterima dan hipotesis 7, hipotesis 8, hipotesis 9 serta hipotesis 11 ditolak.

\section{Pengaruh Tata Kelola Perusahaan Terhadap Prediktabilitas Laba}

Hasil pengujian pada hipotesis pertama membuktikan bahwa secara bersama sama indikator-indikator mekanisme tata kelola perusahaan yang digunakan dalam penelitian ini, yaitu komposisi dewan komisaris, size dewan komisaris, kepemilikan institusional, kepemilikan manajerial, dan komite audit mempengaruhi prediktabilitas laba. Tata kelola yang efektif harus mengarah pada pengungkapan dan pendapatan yang berkualitas serta pelaporan keuangan yang lebih akurat yang pada akhirnya melindungi kepentingan investor dan menahan oportunisme manajerial. Tata kelola perusahaan yang sistematis memiliki kemampuan untuk menghasilkan keuntungan positif bagi perusahaan, meningkatkan kepercayaan investor, dan memaksimalkan keuntungan pemegang saham (Mollah et al., 2019). Perusahaan yang menerapkan tata kelola yang berkualitas menghasilkan laporan keuangan yang berkualitas tinggi (Davies et al., 2016). Untuk memastikan bahwa manajer menerapkan pilihan akuntansi secara bertanggung jawab dan melaporkan keuangan berkualitas tinggi, maka menerapkan mekanisme tata kelola yang efektif sangat penting (Brown et al., 2014). Dalam kondisi krisis, tata kelola perusahaan yang efektif di perbankan sangat penting untuk dilakukan mengingat besarnya asimetri informasi, ketidakjelasan, dan kompleksitas yang menjadi ciri sektor ini (Levine dalam Mollah, 2019). Sejumlah penelitian memberikan hasil yang sama dengan penelitian ini seperti penelitian yang dilakukan Mollah et al, (2019), Khafid dan Arief (2017) dan Orazalin \& Mahmood (2019).

\section{Pengaruh Komposisi Dewan Komisaris Terhadap Prediktabilitas Laba}

Hasil pengujian pada model regresi 1 dan model regresi 3 memperlihatkan bahwa komposisi dewan komisaris tidak terbukti memengaruhi prediktabilitas laba secara signifikan. Hasil penelitian ini sejalan dengan hasil penelitian Khafid dan Arief (2017) yang juga menunjukkan bahwa prediktabilitas laba 
tidak dipengaruhi oleh komposisi dewan komisaris. Hasil penelitian ini juga sesuai dengan penelitian Wiralestari (2015) yang menyatakan bahwa proporsi komisaris independen tidak memengaruhi kualitas pelaporan keuangan yang berdampak pada kualitas laba yang dihasilkan. Salah satu faktor penyebab tidak kuatnya tata kelola perusahaan yang baik adalah aspek pengawasan dewan komisaris. Pada prakteknya anggota dewan komisaris di perusahaan-perusahaan Indonesia selalu diabaikan fungsi dasarnya sebagai pengawas terhadap direksi. Fungsi pembuat kebijakan dilakukan oleh direksi, sedangkan fungsi supervisor dilakukan oleh komisaris. Penunjukan komisaris independen oleh perusahaan mungkin dilakukan untuk memenuhi peraturan tetapi itu tidak dimaksudkan untuk memelihara tata kelola perusahaan yang baik. Komposisi komisaris independen yang minoritas juga menyebabkan kesulitan dalam pembuatan kebijakan dan melakukan pengawasan.

\section{Pengaruh Size Dewan Komisaris Terhadap Prediktabilitas Laba}

Pengujian pada model regresi 1 dan model regresi 3 berhasil membuktikan bahwa size dewan komisaris memengaruhi prediktabilitas laba secara signifikan. Salah satu faktor yang memengaruhi efektifitas tugas pengawasan dewan komisaris adalah size dewan komisaris. Perlunya pertimbangan pada size dewan komisaris dalam upaya untuk mengamati hubungan antara kualitas laba dan komposisi dewan. (Farooque et al., 2012). Beberapa penelitian memberikan temuan yang sama dengan penelitian ini seperti penelitian Farooque et al., (2012), Dalton et al., dalam Mollah et al., (2019) yang menyatakan bahwa size dewan komisaris yang cenderung lebih besar memungkinkan lebih banyaknya anggota dewan komisaris yang lebih independen dan memberikan banyak kemahiran, kepandaian, pengetahuan, pengalaman dan profesional dalam melakukan pengawasan. Namun temuan penelitian ini berbeda dengan pernyataan Mollah et al., (2019) dimana efek dari ukuran interaktif tata kelola standar pada prediktabilitas laba, khususnya dewan kecil meningkatkan prediktabilitas laba. Untuk lebih memudahkan pengaturan, kecepatan pengambilan keputusan, kecenderungan memperoleh masalah freeloaders dan kecenderungan menolak perubahan, size dewan komisaris yang lebih kecil yang lebih disukai (Dimitropoulos dan Asteriou dalam Mollah et al., 2019). Xie et al., dalam Orazalin, (2019) mengungkapkan bahwa size dewan komisaris yang cenderung lebih kecil tidak terlalu dibebani oleh masalah otoritas dan memiliki kemungkinan lebih efisien. Investor menggunakan informasi pendapatan yang diungkapkan oleh perusahaan dengan dewan kecil untuk memperkirakan arus kas masa depan.(Nor dan Ku, 2013)

\section{Pengaruh Kepemilikan Institusional Terhadap Prediktabilitas Laba}

Berdasarkan hasil penelitian pada model regresi 1 dan model regresi 3 menunjukkan kepemilikan institusional diketahui memengaruhi secara signifikan prediktabilitas laba. Kepemilikan institusional adalah mekanisme tata kelola eksternal yang sangat penting dan efektif. Kelompok investor ini berada dalam posisi untuk mempengaruhi praktik yang diadopsi oleh perusahaan dan kehadiran mereka dapat menyebabkan perubahan dalam perilaku perusahaan. Hal ini dikarenakan pengawasan lebih efektif yang dilakukan oleh investor institusi. Pemilik institusional adalah lembaga yang memperdagangkan sekuritas dalam volume tinggi. Pemegang saham institusional karena persentase kepemilikan sahamnya yang tinggi berada dalam posisi untuk melakukan kontrol atas tindakan manajer. Mempertimbangkan kekuatan dan motif investor institusional dalam membujuk manajer untuk memberikan laporan laba yang berkualitas tinggi dan dalam memberikan mereka insentif untuk peningkatan kinerja. Pemilik institusional memiliki akses ke informasi rahasia perusahaan, dalam penentuan harga saham dan mereka mengandalkan informasi historis, dan dengan meyakinkan manajer untuk pelaporan yang tepat waktu dan akurat, mereka pada akhirnya berkontribusi pada peningkatan pelaporan keuangan termasuk kualitas pendapatan (Mokhtari \& Khosro, 2013). Investor juga menggunakan informasi pendapatan yang diungkapkan oleh perusahaan dengan kepemilikan saham tinggi oleh investor institusional untuk 
memperkirakan arus kas masa depan (Nor dan $\mathrm{Ku}, 2013)$. Hasil yang diperoleh ini sesuai dengan Jiang dan Anandarajan, (2009) yang mengungkapkan bahwa salah satu pihak yang dapat mengawasi kinerja agen adalah kepemilikan institusional. Besarnya kehadiran investor institusional mampu menahan dan menekan manajer dari tindakan melakukan pengelolaan laba. Kepemilikan saham institusional memiliki peran saat kondisi komisaris independen tidak efektif mengawasi kinerja perusahaan atau sebaliknya (Wardhani, 2007).

\section{Pengaruh Kepemilikan Manajerial Terhadap Prediktabilitas Laba}

Tabel 3 dan tabel 4 pada hasil pengujian membuktikan bahwa kepemilikan manajerial juga diketahui berpengaruh secara fundamental terhadap prediktabilitas laba. Pengawasan yang lebih ketat meningkatkan kualitas pelaporan laba dengan mengurangi praktik manajemen laba bahkan dengan adanya kepemilikan saham manajerial yang besar. Struktur kepemilikan saham perusahaan memiliki dampak yang signifikan pada agency cost yang melekat dalam hubungan pemegang saham-manajer, sejauh hal itu memengaruhi efisiensi mekanisme pemantauan yang diterapkan. Baik agency theory dan bukti empiris menunjukkan bahwa kemampuan dan insentif pemilik untuk melakukan upaya pemantauan dan mengurangi masalah keagenan bervariasi dengan struktur kepemilikan manajerial (Bourkhis, 2017). Hasil temuan peneltian ini selaras dengan yang dinyatakan oleh Khafid (2015) yaitu kepemilikan manajerial dapat menambah nilai kualitas keuntungan yang dihasilkan. Untuk lebih meningkatkan kinerja manajer, secara efektif dapat dilaksanakan dengan kewajiban mempunyai saham perusahaan. Hal tersebut memberikan kemungkinan bagi dewan direksi untuk lebih dapat melakukan pengawasan terhadap kinerja para manajer. Pendisiplinan para manajer dapat kurang efektif dilakukan jika dewan direksi memiliki sedikit modal saham. Namun hasil ini berbeda dengan yang dinyatakan Isenmila dan Elijah (2012), dan Bouvatier et al., (2014) dimana bank dengan konsentrasi kepemilikan lebih tinggi melakukan lebih banyak manajemen laba dan perataan laba yang menurunkan kualitas labanya dibandingkan dengan bank dengan konsentrasi kepemilikan rendah .

\section{Pengaruh Komite Audit Terhadap Prediktabilitas Laba}

Pada tabel 3 dan tabel 4 menunjukkan hasil penelitian bahwa prediktabilitas laba tidak dipengaruhi oleh komite audit. Analisis lebih lanjut mengenai hal ini dapat dilakukan menimbang bahwa komite audit adalah salah satu bagian pada perusahaan di bawah dewan komisaris yang dibuat untuk menciptakan mekanisme pengelolaan manajemen perusahaan dengan harapan dapat memengaruhi kualitas pelaporan dari keuntungan yang dihasilkan. Pengembangan analisis lebih lanjut tentang presensi komite audit pada perbankan di Indonesia dapat dilakukan karena presensi komite audit lebih sekedar hanya bentuk kepatuhan terhadap hukum saja dibandingkan dengan fungsi substantifnya (Khafid, 2015). Hasil penelitian ini tidak selaras dengan penelitian yang dilakukan oleh Hamdan, (2020) yang menyatakan bahwa komite audit berfungsi sebagai mekanisme tata kelola perusahaan yang mengkoordinasikan audit internal, audit eksternal, dan pemantauan kinerja perusahaan dalam mendukung pelaporan keuangan berkualitas tinggi atas kinerja perusahaan. Anggota komite audit yang lebih besar lebih efektif dalam memantau aktivitas manajemen, dan mereka juga lebih baik dalam menjaga proses pelaporan keuangan (Bala \& Kumai, 2015). Komite audit yang lebih aktif, komite audit yang lebih kompeten, pada akhirnya akan menghasilkan jumlah pendapatan dengan prediktabilitas yang tinggi (Nor \& Ku, 2013). Komite audit yang efektif diharapkan dapat meningkatkan kualitas laba untuk memenuhi berbagai tanggung jawab termasuk, mengomentari dan menyetujui kebijakan akuntansi, mereview dan memelihara laporan keuangan serta kecukupan pengendalian internal (Hassan, 2013). Ukuran atau jumlah komite audit berpengaruh positif terhadap kualitas laba (Amin et al., 2018). Anggota komite audit yang lebih besar lebih efektif dalam memantau aktivitas manajemen, dan mereka juga lebih baik dalam menjaga proses pelaporan keuangan. (Sharma \& Kuang, 2014). 


\section{Pengaruh Moderasi Gender Pada Hubungan Kausalitas Tata Kelola Perusahaan Terhadap Prediktabilitas Laba}

Hasil pengujian pada tabel 4 menunjukkan bahwa gender sebelum diuji signifikansinya sebagai variabel moderating, gender diuji terlebih dahulu sebagai variabel bebas (independent variable). Hal tersebut dilaksanakan sebagaimana umumnya pengujian variabel moderating dilakukan (Ghozali, 2018). Hasil pengujian variabel gender sebagai variabel independen menunjukkan bahwa gender tidak berpengaruh secara signifikan terhadap prediktabilitas laba. Namun hasil pengujian ini menunjukkan bahwa interaksi antara variabel kepemilikan manajerial dengan gender menunjukkan terdapatnya efek moderator jenis pure moderator. Kepemilikan saham bagi manajemen bisa menjadi instrumen utama untuk insentif manajemen. Dengan kata lain kepemilikan saham sudah dapat menjadi pemicu utama dalam peningkatan kinerja perusahaan, dan berdasarkan pemahaman ini harapan bahwa hubungan yang positif antara kepemilikan manajerial dan kualitas laba akuntansi dengan adanya perempuan dalam dewan perusahaan diharapkan dapat terjadi. Abbott et al., (2012) menyatakan bahwa terdapat beberapa nilai lebih yang dimiliki oleh perempuan di dalam dewan, yaitu:

1. Tugas-tugas direktur perusahaan dapat dikendalikan oleh anggota dewan perempuan.

2. Anggota dewan perempuan juga cenderung sebagai anggota dalam komite audit.

3. Anggota dewan perempuan lebih memiliki pengetahuan tentang pengelolaan keuangan yang lebih baik dari pada anggota dewan laki-laki.

4. Memiliki tingkat independensi yang lebih tinggi.

Di sisi yang lain hasil dari penelitian ini belum dapat membuktikan secara menyeluruh pengaruh moderasi rasio perempuan dalam dewan pada hubungan kausalitas pelaksanaan mekanisme tata kelola dan prediktabilitas laba dikarenakan pengaruh moderasi gender hanya terjadi melalui indikator kepemilikan manajerial sedangkan pada indikator tata kelola yang lain seperti komposisi dewan komisaris, size dewan komisaris, kepemilikan institusional, kepemilikan manajerial dan komite audit tidak terjadi. Faktor yang dapat menjelaskan mengapa gender tidak mempunyai pengaruh pada hubungan kausalitas komposisi dewan komisaris, size dewan komisaris, kepemilikan institusional, kepemilikan manajerial dan komite audit terhadap prediktabilitas laba adalah konsep gender yang digunakan pada penelitian ini. Konsep gender hanya dilihat dari suatu perbedaan (differences) antara laki-laki dan perempuan yang sifatnya atribut personal dan karakter biologis (seks) laki-laki dan perempuan secara fisik.

Gagasan gender seharusnya lebih merupakan pada sifat yang melekat pada laki-laki maupun perempuan yang dikonstruksi secara sosial maupun kultural. Definisi ini menunjukkan bahwa gender adalah sifat atau karakter maskulin dan feminin dimana keduanya dapat muncul baik pada laki-laki maupun perempuan. Maksudnya adalah seorang laki-laki tidak semata-mata identik dengan salah satu karakter yaitu maskulin, namun juga memiliki karakter feminin dalam dirinya. Selain itu, definisi tersebut juga menegaskan bahwa gender adalah suatu produk dari konstruksi sosial budaya. Hal ini berarti konsepsi tentang gender dapat berbeda antar kelompok masyarakat dan berubah seiring dengan perkembangan zaman. Konsep gender sangat terkait erat dengan faktor fisik atau biologis. Perbedaan karakteristik fisik antara laki-laki dan perempuan menciptakan konstruksi peran dan fungsi sosial tertentu serta ekspektasi perilaku yang seharusnya ada atau melekat pada laki-laki atau perempuan. Hal ini menunjukkan bahwa memahami gender sebagai perbedaan tidak lagi hanya terkait dengan hubungan personal tapi juga struktur sosial karena perbedaan gender telah melegitimasi ketidaksetaraan sosial yang lebih menghargai laki-laki daripada perempuan. Penyebab mengapa karakter maskulin mendapat nilai atau status yang lebih tinggi daripada karakter feminitas tidak hanya terkait dengan fakta perbedaan biologis tapi juga karena eksistensi struktur sosial yang melembagakan kontrol laki-laki terhadap perempuan. Pada tahap inilah perbedaan gender telah menciptakan ketidaksetaraan gender (gender inequality) dalam sistem ekonomi, sosial dan politik. 
Hasil penelitian ini sejalan dengan penelitian Berger et al., (2014) yang menyatakan bahwa rasio yang lebih tinggi dari anggota dewan perempuan meningkatkan risiko portofolio. Namun hasil penelitian ini tidak mendukung hasil penelitian yang dilakukan oleh Saona et al., (2019), Na dan Hong (2017), El-Mahdy (2015), Liu et al., (2014), Huang \& Kisgen (2013). Bermanfaat memiliki dewan yang seimbang dalam hal keragaman gender. Sebuah dewan yang diseimbangkan cenderung mengurangi praktik pengelolaan laba Keragaman yang lebih dalam dewan berkontribusi pada peningkatan perkiraan pendapatan dan lebih banyak kehadiran perempuan di dewan direksi menyebabkan lebih sedikit praktik manipulasi laba (Saona et al., 2019). Perusahaan dengan laki-laki pada dewan cenderung melaporkan akrual diskresioner yang secara signifikan mengambil tindakan nyata untuk mencapai peningkatan laba (Na dan Hong, 2017). Perusahaan yang memiliki dewan yang beragam cenderung lebih tinggi dividen yang dibayarkan dibandingkan perusahaan dengan anggota dewan yang tidak beragam (Byoun et al., 2016). Dewan yang beragam akan dapat meningkatkan fungsi monitoring serta kebebasan dewan yang akhirnya akan memberikan dampak yang baik bagi para pemegang saham. Adanya perempuan dalam dewan perusahaan menunjukkan bahwa perusahaan memberikan apresiasi dan kesempatan yang sama tanpa adanya diskriminasi. Dewan perempuan lebih kecil kemungkinannya untuk mengelola pendapatan melalui operasi aktivitas nyata dalam standar akuntansi yang berlaku umum dibandingkan dengan dewan laki-laki (ElMahdy, 2015). Persentase dewan wanita memiliki pengaruh yang signifikan dan positif terhadap kinerja perusahaan yang diukur dengan laba atas penjualan dan laba atas aset. (Liu et al., 2014) Wanita yang dipekerjakan rata-rata akan lebih berkualitas, karena mampu mengatasi preferensi diskriminatif, sehingga keputusan yang diambil oleh eksekutif wanita akan lebih baik untuk nilai pemegang saham. Wanita juga membuat posisi keuangan dan investasi perusahaan yang berbeda keputusan daripada laki-laki. Perusahaan dengan eksekutif wanita lebih kecil kemungkinannya untuk melakukan akuisisi dan lebih kecil kemungkinannya untuk menerbitkan hutang dibandingkan perusahaan dengan eksekutif pria. Investor juga bereaksi lebih baik terhadap keputusan keuangan perusahaan yang signifikan yang dibuat oleh perusahaan dengan eksekutif wanita. Laki-laki terlalu percaya diri dengan menunjukkan bahwa pria memberikan perkiraan pendapatan yang lebih sempit dan cenderung tidak menggunakan opsi lebih awal (Huang \& Kisgen, 2013).

Analisa lebih lanjut, hasil pengujian model 3 pada tabel 4 juga menunjukkan bahwa variabel gender termasuk dalam variabel moderasi jenis pure moderator pada pengaruh kepemilikan manajerial terhadap prediktabilitas laba yang ditunjukkan pada nilai signifikansi variabel interaksi gender dan kepemilikan manajerial sebesar 0,031 kurang dari 0,05 . Gender berhasil menjadi variabel moderasi hanya pada pengaruh kepemilikan manajerial terhadap prediktabilitas laba. Sedangkan peran moderasi gender pada pengaruh komposisi dewan komisaris, size dewan komisaris, kepemilikan institusional dan komite audit terhadap prediktabilitas laba tidak terjadi sehingga dapat dikatakan bahwa variabel gender termasuk variabel moderating tipe homologiser moderator yang artinya variabel tersebut potensial menjadi variabel moderasi. Variabel gender tersebut termasuk jenis homologizer dikarenakan tidak berinteraksi dengan variabel independen dan tidak berhubungan dengan variabel dependen.

\section{Simpulan}

Berdasarkan pada model penelitian empiris, hasil pengolahan data dan pembahasan di atas, maka dapat disimpulkan beberapa hal sebagai berikut:

1. Hasil penelitian ini membuktikan bahwa secara bersama-sama komposisi dewan komisaris, size dewan komisaris, kepemilikan institusional, kepemilikan manajerial dan komite audit berpengaruh secara signifikan terhadap prediktabilitas laba. Hal ini menunjukkan bahwa perlunya perluasan kecukupan pelaksanaan tata kelola perusahaan dan manajemen risiko pada bank dengan tujuan agar permasalahan yang akan terjadi dapat dikenali lebih awal dan dapat dilakukan tindak lanjut untuk penyempurnaan secara lebih cepat, sehingga bank dapat bertahan meskipun 
dalam keadaan darurat. Hasil penelitian ini juga berhasil membuktikan bahwa prediktabilitas laba dipengaruhi secara parsial dan signifikan oleh size dewan komisaris, kepemilikan institusional, kepemilikan manajerial. Di sisi lain tidak berhasil membuktikan bahwa komposisi dewan komisaris dan komite audit berpengaruh secara signifikan terhadap prediktabilitas laba.

2. Moderasi gender tidak terjadi melalui hubungan kausalitas antara komposisi dewan komisaris, size dewan komisaris, kepemilikan institusional, komite audit dan prediktabilitas laba, di sisi lain moderasi gender terjadi melalui hubungan kausalitas antara kepemilikan manajerial dan prediktabilitas laba. Hal ini menunjukkan bahwa kepemilikan saham oleh manajemen sebagai bagian insentif dan melihat isu gender dalam perlakuan manusia dengan sikap feminism membuat sistem insentif ini dapat memotivasi manajemen meningkatkan kinerja dan menyesuaikan potensi perbedaan kepentingan antara pemegang saham lainnya dan manajemen.

Penelitian ini secara garis besar berkontribusi mengafirmasi kembali peran dan pengaruh kehadiran perempuan dalam susunan anggota dewan perusahaan, walaupun sebagian hasilnya memberikan inkonsistensi dan saling berlawanan, tetapi memiliki makna signifikan terutama apabila mengingat fakta diskriminasi yang masih terjadi oleh banyak perempuan di bidang keuangan di berbagai negara.

Penelitian ini masih banyak memiliki keterbatasan, gagasan mengenai gender yang dikaji terbatas pada isu gender yang terkait dengan karakter feminism yang ada dalam perusahaan tanpa melihat perbedaan gender terkait karakter feminim dan karakter maskulin yang dibentuk dari variabel sosial maupun budaya di berbagai bidang ekonomi, sosial dan budaya. Untuk penelitian mendatang dapat dilakukan, dengan mempertimbangkan isu gender dalam sudut pandang feminim sesuai dengan teori budaya pada bidang atau organisasi yang lain selain organisasi di bidang jasa. Selain itu juga bisa dilakukan dengan mempertimbangkan perlakuan manusia dengan karakter feminism pada karakteristik jajaran dewan komisaris dan direksi, dimana pada akhirnya penunjukkan komisaris independen dilakukan berdasarkan pada profesionalisme dan kompetensi yang dimiliki oleh seseorang tanpa melihat perbedaan gender dengan karakter feminisme maupun karakter maskulin.

\section{Daftar Pustaka}

Abbott, L. J., Parker, S., \& Presley, T. J. (2012). Female board presence and the likelihood of financial restatement. Accounting Horizons, 26(4), 607-629. https://doi.org/10.2308/acch-50249

Abdul-qadir, A. B. (2012). Corporate Governance and Financial Performance of Banks in the Post-Consolidation Era in Nigeria. International Journal of Social Sciences and Humanity Studies, 4(2), 27-36.

Adebiyi, W. K. (2017). Board Composition and Financial Reporting Quality of Deposit Money Banks in Nigeria. International Journal of Innovative Finance and Economics Research, 5(4), 97-104.

Afnan, A., \& Rahardja. (2014). Pengaruh Ukuran Dewan Komisaris dan Proporsi Komisaris Independen Terhadap Kinerja Keuangan dengan Manajemen Laba Sebagai Variabel Intervening. Diponegoro Journal of Accounting, 3(3), 1-13.

Amin, A., Lukviarman, N., Suhardjnato, D., \& Setiany, E. (2018). Audit Committee Characteristics and Audit- Earnings Quality: Empirical Evidence of the Company with Concentrated Ownership. Review of Integrative Business and Economics Research, 7(Supplementary Issue 1), 18-33. https://search.proquest.com/docview/19 69779323/fulltextPDF/48FDC91C1AC 642DCPQ/27? accountid $=31731$

Anggraeni, D. Y., dan Djakman, C. D. (2017). Slack resources, Feminisme Dewan, dan Kualitas Pengungkapan Tanggung Jawab Sosial Perusahaan. Jurnal Akuntansi Dan Keuangan Indonesia. 14(1), 94-118.

Aprilliani, R., \& H, A. (2017). Pengaruh Ukuran Dewan Komisaris dan Komite Audit Terhadap Manajemen Laba Pada Prusahaan Manufaktur yang Terdaftar 
di Bursa Efek Indonesia Periode 2013 2015. Jurnal Mercu Buana, 10(3), 360372.

Bala, H., \& Kumai, B. (2015). In tern a tio $n$ a 1 Sch o la rs Jo u rn a ls Audit committee characteristics and earnings quality of listed food and beverages firms in Nigeria. International Journal of Accounting, 2(8), 216-227.

Beji, R., Yousfi, O., Loukil, N., \& Omri, A. (2020). Board Diversity and Corporate Social Responsibility: Empirical Evidence from France. Journal of Business Ethics, May. https://doi.org/10.1007/s10551-02004522-4

Berger, A. N., Kick, T., \& Schaeck, K. (2014). Executive board composition and bank risk taking. Journal of Corporate Finance, 28, 48-65. https://doi.org/10.1016/j.jcorpfin.2013.1 1.006

Bougie, \& Sekaran. (2016). Research Methods for Business: A skill Building Approach (7th Ed.). New York: John wiley@Sons.

Bourkhis, K. (2017). The Effect of Ownership and Regulation on Bank Earnings Quality an investigation of the conventional and Islamic banks in MENA region. European Journal of Islamic Finance, $0(6)$. https://doi.org/10.13135/24212172/2047

Bouvatier, V., Lepetit, L., \& Strobel, F. (2014). Bank income smoothing, ownership concentration and the regulatory environment. Journal of Banking and Finance, 41(1), 253-270. https://doi.org/10.1016/j.jbankfin.2013. 12.001

Brown, N. C., Pott, C., \& Wömpener, A. (2014). The effect of internal control and risk management regulation on earnings quality: Evidence from Germany. Journal of Accounting and Public Policy, 33(1), 1-31. https://doi.org/10.1016/j.jaccpubpol.201 3.10 .003

Byoun, S., Chang, K., \& Kim, Y. S. (2016). Board Diversity and Corporate Payout Policy. Asia-Pacific Journal of Financial Studies, 45(1), 48-101.

Davies, L.O.N, Gberegbe, F. B., Ofurum, C. O., \& Egbe, S. E. (2016). Corporate
Governance and Earnings Quality of Listed Banks in Rivers State. International Journal of Business and Management Invention, 5(7), 29-33.

Dichev, I. D., Graham, J. R., Harvey, C. R., \& Rajgopal, S. (2012). Earnings quality: Evidence from the field. Journal of Accounting and Economics, 56(2-3), 1-33. https://doi.org/10.1016/j.jacceco.2013.0 5.004

Du, K., Huddart, S., Xue, L., \& Zhang, Y. (2020). Using a hidden Markov model to measure earnings quality. Journal of Accounting and Economics, 69(2-3), 101281.

https://doi.org/10.1016/j.jacceco.2019.1 01281

El-Mahdy, D. F. (2015). Female CFOs and Real Earnings Management. American Accounitng Association Annual Meeting, August 2015, 1-45.

Erkens, D. H., Hung, M., \& Matos, P. (2012). Corporate governance in the 2007-2008 financial crisis: Evidence from financial institutions worldwide. Journal of Corporate Finance, 18(2), 389-411.

https://doi.org/https://doi.org/10.1016/j. jcorpfin.2012.01.005

Farooque, O. Al, Mollah, S., \& Karim, A. K. M. W. (2012). Ownership Structure, Board Characteristics and Financial Performance: Evidence from the Botswana Stock Market. SSRN Electronic Journal, January. https://doi.org/10.2139/ssrn.1635681

Folajimi, F. A., Salawu, R. O., \& Shiyanbola, A. A. (2019). Effect of Corporate Governance on Earnings Quality of Quoted Financial and Non-Financial Firms in Nigeria. Quest Journals Journal of Research in Business and Management, 7(3), 40-51.

Ghozali, Imam. (2018). Aplikasi Analisis Multivariate dengan Program IBM SPSS 25. Badan Penerbit Universitas Diponogoro. Semarang

Ginting, E. K. P. B. (2014). Pengaruh Kualitas Audit dan Prediktabilitas terhadap Earnings Response. Artikel, 1(1), 1-29.

Hambrick, D. C. (2016). Upper Echelons Theory. In The Palgrave Encyclopedia of Strategic Management (pp. 1-5). 
https://doi.org/10.1057/978-1-3494848-2_785-1

Hamdan, A. (2020). The role of the audit committee in improving earnings quality: The case of industrial companies in GCC. Journal of International Studies, 13(2), 127-138. https://doi.org/10.14254/20718330.2020/13-2/9

Hassan, S. U. (2013). Financial Reporting Quality , Does Monitoring Characteristics Matter? An Empirical Analysis of Nigerian Manufacturing Sector . The Business \& Management Review, 3(2), 147-161.

Heirany, F., Sadrabadi, A. N., \& Mehrjordi, F. F. (2013). Investigating the Effect of Corporate Governance Mechanisms on the Quality of Accounting Profit. International Journal of Academic Research in Accounting, Finance and Management Sciences, 3(3), 315-328. https://doi.org/10.6007/ijarafms/v3i3/221

Huang, J., \& Kisgen, D. J. (2013). Gender and corporate finance: Are male executives overconfident relative to female executives? Journal of Financial Economics, 108(3), 822-839. https://doi.org/10.1016/j.jfineco.2012.1 2.005

Ikatan Akuntan Indonesia. (2011). Standar Akuntansi Keuangan. Salemba Empat. Jakarta.

Isenmila, P., \& Elijah, A. (2012). Earnings Management and Ownership Structure: Evidence from Nigeria. Research Journal of Finance and Accounting, 3(7), 22222847.

Jensen, M. C., \& Meckling, W. H. (1976). Theory of the firm: Managerial behavior, agency costs and ownership structure. Journal of Financial Economics, 3(4), 305-360. https://doi.org/https://doi.org/10.1016/0 304-405X(76)90026-X

Jiang, W., \& Anandarajan, A. (2009). Shareholder rights, corporate governance and earnings quality: The influence of institutional investors. Managerial Auditing Journal, 24(8), 767-791.

https://doi.org/10.1108/0268690091098 6402

Jiraporn, P., Kim, J.-C., Kim, Y. S., \&
Kitsabunnarat, P. (2012). Capital structure and corporate governance quality: Evidence from the Institutional Shareholder Services (ISS). International Review of Economics \& Finance, 22(1), 208-221. https://doi.org/https://doi.org/10.1016/j. iref.2011.10.014

Journal Enterpreneur. (2021, 2 Februari) Kenali Fraud Laporan Keuangan dan Praktiknya yang Merugikan Perusahaan. Diakses pada 2 Februari 2021 dari https://www.jurnal.id

Khafid, M., \& Arief, S. (2017). Managerial ownership, corporate governance and earnings quality: The role of institutional ownership as moderating variable. Pertanika Journal of Social Sciences and Humanities, 25(October 2017), 241-254.

Khafid, M. (2015). Peran Moderasi Kepemilikan Institusional Terhadap Determinan Prediktabilitas Laba. Konferensi Regional Akuntansi II. Jawa Timur.

Khan, M. T., Khan, A. W., Mardan, U., \& Khan, I. (2018). The Impact of Corporate Governance on Earnings Management: Empirical Evidence from Pakistan. Journal of Research in Social Sciences, 6(2), 2305-6533.

Kodriyah. (2015). Pengaruh Kepemilikan Institusional, Ukuran Perusahaan, Leverage dan Good Corporate Governance Terhadap Manajemen Laba. Jurnal Akuntansi, 2(1)

Khuza'i, M. (2012). Problem Definisi Gender: Kajian Atas Konsep Nature Dan Nurture. Kalimah, 11(1), 102. https://doi.org/10.21111/klm.v11i1.486

Kumar, S. (2016). The Evolution of Corporate Governance And The concerns And Challenges. 7(5), 153163.

Lee, Y.-C. (2013). Can Independent Directors Improve the Quality of Earnings? Evidence from Taiwan. Advances in Management \& Applied Economics, 3(3), 45-66.

Liputan6.com. (2021, 4 Februari). Pandemi Covid 19 Bikin Laba Perbankan Melempem. Diakses pada 5 Februari 2021 dari http://www.liputan6.com

Liu, Y., Wei, Z., \& Xie, F. (2014). Do women directors improve firm 
performance in China? Journal of Corporate Finance, 28, 169-184. https://doi.org/10.1016/j.jcorpfin.2013. 11.016

Matud, M. P., Bethencourt, J. M., \& Ibáñez, I. (2015). Gender differences in psychological distress in Spain. International Journal of Social Psychiatry, 61(6), 560-568. https://doi.org/10.1177/0020764014564 801

McKinsey and Company. (2010). McKinsey Global Survey Results: Moving Women to the Top Survey. New York: McKinsey and Company.

Meyer and Levy, J. (1986). Gender Differences in Information Processing: A Selectivity Interpretation. In Cognitive and Affective Responses to Advertising., Edited by P., Cafferata and M. Tybout., 219-260,. MA: Lexington Books., Lexington

Mokhtari, Z., \& Khosro, F. M. (2013). Relationship of Institutional Ownership with Firm Value and Earning Quality: Evidence from Tehran Stock Exchange. International Journal of Economy, Management, and Social Sciences, 7(2), 495-502.

Mollah, S., Al Farooque, O., Mobarek, A., \& Molyneux, P. (2019). Bank Corporate Governance and Future Earnings Predictability. Journal of Financial Services Research, 56(3), 369-394. https://doi.org/10.1007/s10693-01900307-7

Mollah, S., Farooque, O. Al, Asma, M., \& Molyneux, P. (2015). Corporate Governance and Earnings Predictability in Banks. SSRN Electronic Journal, 135.

https://doi.org/10.2139/ssrn.2607098

Na, K., \& Hong, J. (2017). CEO gender and earnings management. Journal of Applied Business Research, 33(2), 297308.https://doi.org/10.19030/jabr.v33i2. 9902

Naharin, N. (2017). Subordinasi Perempuan Dalam Organisasi (Organisasi Mahasiswa Iain Tulungagung Tahun 2015). In Martabat: Jurnal Perempuan dan Anak. Vol. 1(1). https://doi.org/10.21274/martabat.2017. 1.1.175- 196

Nor, K., \& Ku, I. (2013). Governance
Structure , Ownership Structure And Earnings Predictability. Asian Academy of Management Journal of Accounting and Finance, 9(1), 1-23.

Orazalin, N. (2019). Board gender diversity, corporate governance, and earnings management: Evidence from an emerging market. Gender in Management, 35(1), 37-60. https://doi.org/10.1108/GM-03-20180027

Orazalin, N., \& Mahmood, M. (2019). The financial crisis as a wake-up call: corporate governance and bank performance in an emerging economy. Corporate Governance (Bingley), 19(1), 80-101. https://doi.org/10.1108/CG-02-20180080

Peraturan Otoritas Jasa Keuangan. (2016). Penerapan Manajemen Risiko Bagi Bank Umum. Peraturan Otoritas Jasa Keuangan Nomor 18/POJK.03/2016. Jakarta: Otoritas Jasa Keuangan

Prastiwi, O. T., \& Wiratno, A. (2021). Pengaruh Available Slack, Diversifikasi Gender dan Debt To Equity Ratio Terhadap Kualitas Pengungkapan Tanggung Jawab Sosial Perusahaan. Jurnal Ekonomi, Bisnis dan Akuntansi Vol. 23(1), 45-58

Prior D, Tortosa-Ausina E, Illueca $\mathrm{M}$, García-Alcober MP (2014) Earnings quality and performance in the banking industry: A profit frontier approach, Working Papers series no. 2014/11. Economics Department, Universitat Jaume I, Castellón

Saksessia, D., \& Firmansyah, A. (2020). The role of corporate governance on earnings quality from positive accounting theory framework. International Journal of Scientific and Technology Research, 9(1), 808-820.

Salehi, M., \& Asgari, A. (2013). Corporate governance and earnings quality: the Iranian evidence. Journal of Distribution Science, 11(6), 5-11. https://doi.org/10.15722/jds.11.6.20130 6.5

Saona, P., Muro, L., San Martín, P., \& BaierFuentes, H. (2019). Board of director's gender diversity and its impact on earnings management: An empirical analysis for select european firms. 
Technological and Economic Development of Economy, 25(4), 634663.

https://doi.org/10.3846/tede.2019.9381

Schiemann, F., \& Guenther, T. (2013). Earnings predictability, value relevance, and employee expenses. International Journal of Accounting, 48(2), 149-172. https://doi.org/10.1016/j.intacc.2013.04. 001

Sharma, V. D., \& Kuang, C. (2014). Voluntary audit committee characteristics, incentives, and aggressive earnings management: Evidence from New Zealand. International Journal of Auditing, 18(1), 76-89. https://doi.org/10.1111/ijau.12013

Scott, R., William (2012), Financial Accounting Theory. 7th Edition Hardcover. Prentice Hall.

Surat Edaran Bank Indonesia. (2013). Pelaksanaan Good Corporate
Governance Bagi Bank Umum. Surat Edaran Bank Indonesia No. 15/15/DNP. Jakarta: Bank Indonesia Wardhani. (2009). "Pengaruh Proteksi Bagi Investor, Konvergensi Standar Akuntansi, Implementasi Corporate Governance, dan Kualitas Audit Terhadap Kualitas Laba: Analisis Lintas Negara di Asia". Jakarta. Disertasi Universitas Indonesia.

Wiralestari. (2015). Board of commissioners' characteristics toward financial reporting's quality: Non-financial issuers listed in Indonesia Stock Exchange. International Journal of Applied Business and Economic Research, 13(8), 6619-6627

Yogiswari, N. L. P. P., \& Badera, I. D. N. (2019). Pengaruh board diversity terhadap kinerja perusahaan dalam perspektif corporate governance pada perusaahaan manufaktur di BEJ 2005. E-Jurnal Akuntansi, 26, 2070 